\title{
ANALISIS KELAYAKAN USAHA MESIN PERONTOK PADI(THRESHER) DI DUSUN KONANGKA (STUDI PADA DESA BLIMBING, KECAMATAN KLABANG, KABUPATEN BONDOWOSO)
}

\author{
Muhlis Sodiq Fadilla1), Martono Achmar ${ }^{2 *}$ \\ Program Studi Agribisnis, Fakultas Pertanian, Universitas Abdurachman Saleh Situbondo \\ Email Korespondensi :
}

\begin{abstract}
Abstrak
Penelitian ini bertujuan untuk mengetahui pendapatan dan penerimaan penyedia usaha mesin perontok padi Thresher, dengan dilihat dari Perkembangan teknologi dan ilmu pengetahuan menjadikan alat-alat dan mesin pertanian juga mengalami perkembangan dan pembaharuan. Dengan tersedianya usaha mesin perontok padi di Dusun Konangka ini perlu di keahui juga sebuah analisis kelayakan usaha yang sedang di jalankan. Penelitian ini dilakukan pada Dusun Konangka, Desa Belimbing, Kecamatan Kelabang, Kabupaten Bondowoso. Dimulai dari bulan juni hingga agustus. Metode yang di gunakan dalam penelitian ini yakni studi kasus. Pengumpulan data dilakukan dengan metode kualitatif dan kuantitatif dengan sampel Nonprobability Sampling. Analisis yang di gunakan dalam penelitian ini adalah analisis ratio penerimaan atas biaya (R/C Ratio) untuk mengetahui perbandingan antara penerimaan dan biaya yang dikeluarkan. Untuk Analisis yang kedua dalam penelitian ini digunakan analisis kelayakan usaha yakni (B/C Ratio) dengan menghitung jumlah pendapatan dibagi dengan total biaya produksi. Dengan hasil penelitian menunjjukkan kedua mesin tersebut dikategorikan layak untuk diteruskan karena alat tersebut saling memberikan kontribusi terhadap petani maupun penyedia jasa baik dari segi efisiensi dan keuntungan.
\end{abstract}

Kata kunci : pendapatan, penerimaan, Thresher.

\begin{abstract}
This study aims to determine the income and acceptance of the Thresher rice thresher machine business provider, by looking at the development of technology and science, making agricultural tools and machines also experience development and renewal. With the availability of the rice thresher machinery business in Konangka Hamlet, it is also necessary to know an analysis of the feasibility of the business being carried out. This research was conducted in Konangka Hamlet, Blimbing Village, Kelabang District, Bondowoso Regency. Starting from June to August. The method used in this research is a case study. Data collection is done by qualitative and quantitative methods with a sample Nonprobability Sampling. The analysis used in this study is the analysis of the ratio of receipts to costs $(R / C$ Ratio) to determine the comparison between revenues and costs incurred. For the second analysis in this study used a business feasibility analysis (B / C Ratio) by
\end{abstract}

Keywords: Income, Revenue, Thresher

\section{PENDAHULUAN}

Di jaman yang serbah canggih ini semua kegiatan mulai didukung dengan teknologi. Sejalan dengan berkembangnya teknologi dari waktu-kewaktu cara pemanenan hasil pertanian juga ikut mengalami perkembangan sesuai kebutuhan. Banyak sekali teknologiteknologi baru yang mulai muncul sehingga memudahkan para petani untuk melakukan kegiatan budidaya (Ali, 2015).

Tujuan dari sistem pemanenan padi secara tradisional maupun moderen sejatinya sama kesejahteraan petani dan ketahanan pangan nasional maupun lokal. Jadi bisa kita 
simpulkan bahwa sistem panen padi tetap sama, yang membedakan yaitu proses didalam sistem tersebut yan mengikuti kamajuan teknologi. Dilain pihak pengembangan budidaya padi skal besar (rice estate) di Indonesia harus terus diupayakan dengan menggunakan teknologi modern di lahan-lahan di luar pulau jawa. Dan tentu saja akan membutuhkan dukungan berupa investasi yang cukup besar untuk mempersiapkan sarana dan prasarananya (Sulistiaji, 2007).

Thresher merupakan alat untuk merontokkan padi menjadi gabah. Alat ini merupakan alat bantu bagi tenaga kerja untuk memisahkan gabah dengan jeraminya sehingga penggunaan thresher menjadi satu kesatuan dengan tenaga kerja panen. Terdapat dua jenis thresher berdasarkan alat penggeraknya yaitu pedal thresher dan power thresher dimana pedal thresher di gerakkan oleh tenaga manusia dengan cara di pedal dan power thresher sudah menggunakan mesin jenis disel. Kedua mesin tersebut cocok di aplikasikan di area lahan yang berkapasitas panen luas dimana efisiensi dari kedua alat tersebut sangat tinggi daripada sistem kebot atau manual.

\section{METODE PENELITIAN \\ Populasi dan Sampel}

Pengertian Populasi menurut sugiyono (2013) populasi dalam penelitian kuantitatif dan kualitatif. Penelitian kuantitatif populasi diartikan sebagai wilayah generalisasi yang terdiri atas: obyek/subyek yang mempunyai kualitas dan karakteristik tertentu yang di tetapkan oleh peneliti untuk dipelajari dan kemudian di tarik kesimpulannya.

Pengertian sampel menurut sugiyono (2017) adalah bagian dari jumlah dan karakteristik yang di miliki oleh populasi tersebut dalam Penelitian ini penaliti menggunakan Jenis nonprobability sampling yang digunakan dalam penelitian ini adalah sampling jenuh atau sering disebut juga sensus. hal ini dilakukan bila jumlah populasi relatif kecil kurang dari 30, atau penelitian yang ingin membuat generalisasi dengan kesalahan yang sangat kecil. Istilah lain sampel jenuh adalah sensus, dimana semua populasi dijadikan sampel

\section{Tehnik Analisis Data}

Analisis dilakukan untuk membandingkan biaya-biaya dan manfaatnya dan menentukan proyek-proyek yang mempunyai keuntungan yang layak. Analisis pelaksanaan proyek-proyek pertanian memppunyai implikasi nyata terhadap penerimaan dan pengeluaran petani. Apaila biaya dan manfaat proyek sudah diidentivikasi, dihitung dan dinilai maka analisis sudah dapat menentukan proyek mana yang akan diterima atau ditolak (Gittinger, 1986)

Soekartawi (2002) biaya usaha tani terdiri dari biaya tunai dan non tunai. Biaya tunai merupakan biaya yang dikeluarkan secara tunai. Biaya non tunai merupakan biaya yang tidak termasuk kedalam biaya tunai tetapi diperhitungkan dalam usaha tani. Penerimaan usaha tani adalah perkalian antara produksi yang diperoleh dengan harga jual produk (Soekartawi, 2002). Secara matematis pennerimaan dapat dituliskan sebagai berikut:

Analisis dilakukan dengan cara menggunakan rasio penerimaan atas biaya $(\mathrm{R} / \mathrm{C}$ Ratio). Analisis penerimaan atas biaya (R/C Ratio) merupakan salah satu cara untuk mengetahui perbandingan antara penerimaan dan biaya yang dikeluarkan pada satu kali produksi tiap musim. Analisis rasio penerimaan atas biaya (R/C ratia) memiliki arti sebagai berikut :

a. Apabila nilai $\mathrm{R} / \mathrm{C}>1$ maka usaha jasa tersebut dikatakan menguntungkan karena setiap satu rupiah biaya yang dikeluarkan akan menghasilkan peneriman lebih besar dari satu rupiah/layak.

b. Apabila nilai $\mathrm{R} / \mathrm{C}=1$ maka usaha jasa tersebut dikatakan impas karena setiap satu rupiah biaya yang dikeluarkan seimbang dengan yang di dapat. 
c. Apabila nilai $\mathrm{R} / \mathrm{C}<1$ maka usaha jasa tersebut dikatakan tidak menguntungkan karena setiap satu rupiah biaya yang dikeluarkan akan menghasilkan peneriman lebih sedikit dari satu rupiah/ tidak layak.

Biaya produksi:

$$
\begin{array}{rll}
\text { TC }=\text { TFC }+ \text { TVC } & \\
\text { Keterangan } & : \text { TC } & =\text { Total Cost (total biaya produksi) } \\
& \text { TFC } & =\text { Total Fixed Cost (total biaya tetap) } \\
& \text { TVC } & =\text { Total Variable Cost (total biaya variabel) }
\end{array}
$$

Total penerimaan:

$$
\mathrm{TR}=\mathrm{P} . \mathrm{Q}
$$

Keterangan $\quad:$ TR

$P$

$=$ Total Revenue (total penerimaan)

Q

$=$ Price (harga produksi)

= Quantity (jumlah produksi)

Pendapatan pengusaha:

$$
\pi=\text { TR-TC }
$$

$\begin{array}{lll}\text { Keterangan } & : \pi & =\text { Besar Tingkat Pendapatan } \\ \text { TR } & =\text { Total Revenue (total penerimaan) } \\ \text { TC } & =\text { Total Cost (total biaya produksi) (Soekartawi, } \\ & 1995 \text { ) }\end{array}$

Untuk hipotesa yang kedua yaitu kelayakan usaha mesin perontok padi (thresher) menggunakan (B/C ratio).

Keterangan:

B : Benefit atau jumlah pendapatan

C : Cost atau total biaya produksi

Dengan kriteria sebagai berikut:

A. Bila B/C > 1 maka usaha jasa tersebut dikatakan menguntungkan karena setiap satu rupiah biaya yang dikeluarkan akan menghasilkan keuntungan lebih besar dari satu rupiah/layak.

B. Apabila nilai $\mathrm{B} / \mathrm{C}=1$ maka usaha jasa tersebut dikatakan impas karena setiap satu rupiah biaya yang dikeluarkan seimbang dengan yang di dapat.

C. Bila $\mathrm{B} / \mathrm{C}<1$ maka usaha jasa tersebut dikatakan tidak layak karena setiap satu rupiah biaya yang dikeluarkan akan menghasilkan keuntungan lebih sedikit dari satu rupiah/ tidak layak.

\section{HASIL DAN PEMBAHASAN}

Tabel 1. Pendapatan Mesin Thresher

$$
\text { Penerimaan (Rp) Total Biaya(Rp) Tendapatan(Rp) }
$$

\begin{tabular}{cccc}
\hline Jumlah & $225,150,000$ & 86.813 .750 & 138.336 .250 \\
\hline
\end{tabular}

Pada Tabel 1 di pendapatan Mesin thresher, penerimaan dari total keseluruhan responden yang peneliti wawancarai ada di angka Rp. 225.150.000, sedangkan untuk total biaya yang dikeluarkan dari 35 responden adalah Rp. 86.813.750, pendapatan yang di dapat oleh seluruh responden dari dua mesin perontok padi thresher (pedal dan power) dengan rumus penerimaan dikurangi total biaya adalah Rp. 138.336.250 
Tabel 2. Penerimaan Mesin Thresher.

\begin{tabular}{cccc}
\hline & Pedal Thresher (Rp) & Power Thresher (Rp) & $\begin{array}{c}\text { Total Penerimaan } \\
\text { (Rp) }\end{array}$ \\
\hline Jumlah & 20.400 .000 & 204.750 .000 & 225.750 .000 \\
& & \\
\hline
\end{tabular}

Pada Tabel di atas menunjukkan Penerimaan dari tiap Mesin thresher pada mesin pedal thresher di peroleh angka Rp. 20.400.000 dan pada mesin power thresher total keseluruhan responden yang peneliti wawancarai dan biaya sewa dari 35 responden adalah Rp. 204.750.000. Jadi total penerimaan dari kedua mesin perontok padi baik dari power thresher dan pedal thresher yakni sebesar 225.150.000.

Tabel 3. R/C Ratio Mesin Thresher

\begin{tabular}{rrr}
\hline & Penerimaan (Rp) & \multicolumn{2}{c}{ Total Biaya(Rp) } \\
\hline R/C Ratio & $225,150,000$ & 86.813 .750 \\
\hline
\end{tabular}

Berdasarkan Pada Tabel di atas R/C Ratio Mesin thresher diperoleh Penerimaan sebesar Rp. 225,150,000 dan total biaya sebesar Rp 86.813.750. Dari total keseluruhan responden yang peneliti wawancarai maka $\mathrm{R} / \mathrm{C}$ ratio bisa di ukur dengan Penerimaan dibagi total biaya yang hasilnya berada di angka 2.70 dimana angka tersebut menunjukkan di atas 1 dan usaha pedal thresher tersebut bisa dikatakan menguntungkan karena setiap satu rupiah yang di keluarkan akan menghasilkan penerimaan yang lebih besar dari satu rupiah atau layak dan R/C Ratio di atas memberikan memberikan sumbangsi sebesar $\mathbf{2 . 7 0}$

Tabel 4. Ratio Mesin Thresher

\begin{tabular}{lrr}
\hline & Pendapatan (Rp) & \multicolumn{2}{c}{ Total Biaya (Rp) } \\
\hline B/C Ratio & 138.333 .250 & 65.068 .745 \\
\hline
\end{tabular}

Dari Tabel 4 untuk menguji hipotesis kedua melalui analisa kelayakan, ukuran tingkat kelayakan dapat di hitung dengan sistematikian sebagai berikut:

$\mathrm{B} / \mathrm{C}$ ratio $=\mathbf{1 3 8 . 3 3 3 . 2 5 0} / \mathbf{6 5 . 0 6 8 . 7 4 5}=\mathbf{2 . 1 3}$

$\mathrm{B} / \mathrm{C}$ ratio $=\mathbf{2 . 1 3}$

Pendapatan Mesin thresher diperoleh pendapatan sebesar Rp. 138.333.250 dan total biaya sebesar Rp. 65.068.745 maka benefit cost ratio atau B/C ratio bisa di ukur dengan pendapatan di bagi total biaya yang hasilnya berada di angka 2.13 dimana angka tersebut menunjukkan angka lebih dari 1 dan usaha mesin thresher terbilang layak

\section{Kelayakan Usaha Mesin Thresher}

Berdasarkan total perhitungan sampel pada kedua mesin thresher diperoleh kriteria B/C Ratio > 1 yaitu $(\mathbf{2 , 1 3})$ yang menunjukkan usaha mesin thresher di Dusun Konangka, Desa Blimbing, Kecamatan Klabang, Kabupaten Bondowoso, layak untuk di usahakan dari hasil perhitungan analisa B/C Ratio diperoleh nilai sebesar 1.70. 


\section{KESIMPULAN}

Berdasarkan dari hasil penelitian yang telah di lakukan dan telah di uraikan sebelumnya maka dapat di Tarik kesimpulan dari keseluruhan hasil penelitian yakni :

1. $\quad$ Pendapatan Mesin Thresher sejumlah Rp.138.336.250 dan penerimaan Mesin Thresher sejumlah Rp.225.750.000.

2. Mesin pedal thresher dan power thresher layak di gunakan di Dusun Konangka, Desa Blimbing, Kecamatan Klabang, Kabupaten Bondowoso.

\section{REFERENSI}

Ali. (2015). Pengertian Konflik, Faktor Penyebab dan Macam-macamnya. Diakses dari http://www.pengertianpakar.com/2019/08/pengertian-konflik-faktorpenyebabnya.html

Gittinger, jp 1986 Analisa Ekonomi dan Proyek-Proyek Pertanian Terjamahan. Edisi Kedua. UI-press dan john hopkins Jakarta

Koes Sulistiaji. (2007). Buku Alat dan Mesin (Alsin) Panen dan Perontok Padi di Indonesia. Balai Besar Pengembangan Mekanisasi Pertanian, Serpong

Soekartawi. 2002. Ilmu Usahatani dan Penelitian Untuk Pengembangan Petani Kecil. Universitas Indonesia. Jakarta.

Soekartawi. 1995. Analisis Usahatani . UI Press jakarta

Sugiono. 2013. Metode Penelitian Kualitatif, Kuantitatif dan R\&D. Bandung: ALFABET.

Sugiyono. 2017. Metode Penelitian Kualitatif, Kuantitatif Dan R\&D.bandung: alfabeta ,CV. 